\title{
ANÁLISE MICROSCÓPICA DA MORFOLOGIA DE ESPERMÁTIDES DE SESARMA RECTUM RANDALL (DECAPODA: BRACHYURA)
}

\author{
Lima, A.A. ${ }^{1, *}$ \& Biancalana, A. ${ }^{1}$ \\ ${ }^{1}$ Universidade Federal do Para (UFPA), campus Soure, Laboratório de Biologia Celular e Molecular. \\ *Autor correspondente: alvarolima838@gmail.com; biancalana.a@gmail.com
}

O caranguejo Sesarma rectum, possui uma importância ecológica devido sua contribuição para a aeração e oxigenação do solo, além de serem base da alimentação de alguns vertebrados e invertebrados maiores. No entanto, poucos registros podem ser encontrados na literatura a respeito da reprodução desses crustáceos. O presente trabalho teve o objetivo analisar os diferentes estágios de desenvolvimento morfológico das espermátides durante a espermiogênese do caranguejo $S$. rectum. Ao todo 15 espécimes foram coletados mensurados e dissecados para a retirada dos testículos, o material foi armazenado em microtubos, contendo formalina 10\%. Depois de fixado, o tecido foi armazenado em álcool $70 \%$. Continuando o processamento, os tecidos foram desidratados gradativamente em uma série crescente de etanol. Em seguida foi diafanizado em xilol/álcool 50\%, xilol $100 \%$ I e xilol $100 \%$ II. O material foi levado a uma estufa com parafina histológica aquecida. O tecido foi colocado em Becker com parafina liquida na estufa. Depois o tecido foi retirado do Becker e emblocado em parafina, e deixadas para secar. Os blocos adquiridos foram cortados no micrótomo rotativo, onde foram obtidos cortes histológicos com $7 \mu \mathrm{m}$ de espessura. Os cortes, foram colocados em banho maria, pescados com lâminas. Os mesmos foram corados, utilizando as colorações Hematoxilina-Eosina (HE), Azul de Toluidina (AT). Após coradas as laminas foram montadas com lamínulas e bálsamo do Canadá, tendo como resultado final lâminas permanentes. Com o termino da análise microscópica foi possível caracterizar as espermátides e a divisão das mesmas em três estágios de acordo com o grau de lateralização do núcleo, sendo: espermátides primarias, espermátides intermediárias e espermátides finais. Com o presente estudo concluímos que após o termino das meioses nos espermatócitos, as espermátides sofrem apenas lateralização de seu núcleo. Assim de acordo com o grau de lateralização pode ser definido o estágio em que a célula se encontra.

Palavras-chave: Sesarma rectum, espermátide, lateralização. 